South African Journal for Research in Sport, Physical Education and Recreation, 2010, 32(2): 41-54.

Suid-Afrikaanse Tydskrif vir Navorsing in Sport, Liggaamlike Opvoedkunde en Ontspanning, 2010, 32(2): 41-54. ISSN: 0379-9069

\title{
FACTORS AFFECTING THE RECOVERY-STRESS, BURNOUT AND MOOD STATE SCORES OF ELITE STUDENT RUGBY PLAYERS
}

\author{
Heinrich W. GROBBELAAR*, Dawie D.J. MALAN**, Ben J.M. STEYN*** \& \\ Suria M. ELLIS**** \\ *Department of Sport Science, Stellenbosch University, Stellenbosch, \\ Republic of South Africa \\ ** School for Biokinetics, Recreation and Sport Science, North-West University, \\ Potchefstroom, Republic of South Africa \\ *** Department of Biokinetics, Sport and Leisure Sciences, University of Pretoria, \\ Pretoria, Republic of South Africa \\ **** Statistical Consultation Service, North-West University, Potchefstroom, \\ Republic of South Africa
}

\begin{abstract}
A sample of 41 male student rugby players (mean age: $21.87 \pm 1.39$ years) completed the Recovery-Stress Questionnaire (Kellmann \& Kallus, 2001), Athlete Burnout Questionnaire (Raedeke \& Smith, 2001) and Stellenbosch Mood Scale (Terry et al., 2003) repeatedly over a five-month period. Independent t-tests, oneway analysis of variance and effect sizes were used to indicate significant differences between groups (categorised according to playing position, experience level and starting status). The group of forwards were shown to have significantly $(d \approx 0.5)$ better results than the backline players for 12 of the 39 tested variables. The group of less experienced players had significantly less General and Sport-specific Stress and negative Mood State scores than their very experienced and novice counterparts, whilst the novice players showed greater General and Sport-specific Recovery scores. Differences in starting status were also observed as the reserve players were shown to have significantly higher General and Sport-specific Recovery scores and better Mood State scores than the regular starters. These results suggest that playing position, experience level and starting status should be considered in player management strategies and during the psycho-social monitoring of players aimed at reducing the onset and development of overtraining and burnout.
\end{abstract}

Key words: Overtraining; Recovery-stress; Burnout; Mood States; Rugby.

\section{INTRODUCTION AND PROBLEM STATEMENT}

Numerous physiological, psychological and social stressors are believed to contribute to the onset and development of the overtraining and burnout syndromes (Kenttä \& Hassmén, 1998; Kenttä et al., 2001). In Kenttä and Hassmén's (1998) conceptual model of overtraining and recovery, overtraining and burnout are seen as the negative products of long-term imbalances between the total stressors and total recovery efforts, which exceed an athlete's maximum stress tolerance. Despite the significant contributions of psychological and social stressors, 
increased training loads are still regarded as the greatest contributor to these syndromes. In this regard rugby players have reported heightened exhaustion levels due to increased average weekly training volumes, more games per season and shorter off-seasons (Creswell \& Eklund, 2005). The best treatment for athletes suffering from these conditions seems to be complete rest, but this approach directly opposes the instinctive reaction of coaches and players to increase their training efforts in response to poor performances (Marshall, 2005).

Overtraining can be defined as "a syndrome that results when excessive, usually physical overload on an athlete occurs without adequate rest" (Gould \& Dieffenbach, 2002: 25). Raedeke et al. (2002) conceptualised athlete burnout as an enduring psycho-social syndrome characterised by a reduced sense of accomplishment (a perceived lack of achievement and success), sport devaluation (a decrease of the perceived benefits gained from sport involvement) and emotional and physical exhaustion (feelings of being overextended and exhausted due to sport involvement). These syndromes are distinctly different, although they share certain signs, symptoms and contributing causes.

Between $5.6 \%$ and $24.3 \%$ of rugby players experience burnout symptoms on a frequent basis (Creswell \& Eklund, 2006a), whilst a substantial number (30\%) of team sport athletes have been shown to suffer from overtraining syndrome (Kenttä et al., 2001). The negative impact of these syndromes on the performance and well-being of rugby players is of great concern for coaches, sport psychology consultants, sport scientists, sport medicine personnel and the players themselves (Creswell \& Eklund, 2003).

Grobbelaar et al. (2010) monitored the burnout and recovery-stress levels of rugby players throughout a five-month pre-season, pre-competition and competitive season and reported significant fluctuations during this period. However, this study did not investigate possible contributing factors to the observed changes over time. A number of sport-related factors which affect the recovery-stress, burnout and mood state scores of athletes have been identified (e.g., starting status, playing position and experience level). Raglin and Wilson (2000) found that players not selected in the starting team were more likely to exhibit increases in mood disturbance during intense training than those in the starting line-up. Mashiko et al. (2004) noted that the influence of playing position should be accounted for in the development of recovery strategies directly after the conclusion of rugby matches. It was also revealed that more experienced soccer players had significantly greater positive general mood profiles than less experienced players (Thelwell et al., 2006). From their extensive research on burnout among rugby players, Creswell and Eklund (2005; 2006a; 2006c) deemed factors such as playing position, experience levels and starting status worthy of further investigation as possible contributing factors to the onset and development of burnout.

Subsequently, the aim of this study was to compare elite student rugby players' recoverystress, burnout and mood state scores, based on their playing position, experience level and starting status. Information on the role of these factors on overtraining and burnout scores might assist coaches, sport psychology consultants and sport scientists in the prevention or management of the possible onset and development of these negative experiential syndromes. 


\section{RESEARCH METHODS}

\section{Research design}

A longitudinal research design was implemented. Data were gathered on seven test points (at three-weekly intervals) over a five-month training and competitive period.

\section{Subjects}

Forty-one male rugby union players (with a mean age of $21.87 \pm 1.39$ years at the first data collection point) from a leading club in South Africa, i.e. the North-West University PUK Rugby Institute (NWU-PRI) were included as subjects in this study. They had on average been playing rugby for $13.76 \pm 2.39$ years. These players formed part of the NWU-PRI senior training squad and represented the $1^{\text {st }}$ or $2^{\text {nd }}$ senior teams until after the completion of the 2008 FNB Varsity Cup rugby tournament. In order to qualify for participation in this tournament (which included the top eight tertiary institution teams in South Africa) the subjects had to be 25 years of age or younger and enrolled as students. The subject group is, therefore, a particularly homogenous group, since they were all subject to similar training and competitive stressors (having been part of the same training programme and matches), as well as non-training stressors (studies and general student life).

The decision to study student rugby players was based on availability and their proposed vulnerability to overtrain and burn out due to their sport participation and the added stress of their academic endeavours. Only players who completed at least four of the seven test occasions over the five-month period and who remained in the senior training squad throughout were included in the subject group. Missing data from the final dataset were $13.59 \%$, which is deemed acceptable for repeated measurements over this timeframe.

\section{Research instruments}

\section{The Recovery-Stress Questionnaire for athletes (RESTQ-52 Sport)}

The RESTQ-52 Sport, developed by Kellmann and Kallus (2001) measures the frequency of stressors and recovery activities and provides the coaching staff with important information during the training process. The recovery-stress state indicates the extent to which athletes are physically and/or mentally stressed, whether or not they are capable of using individual strategies for recovery, as well as which strategies they use. The RESTQ Sport consists of two versions (i.e., a 52 and 72 item questionnaire). Kellmann and Kallus (2001) recommend the use of the 52 item version in longitudinal research designs such as the present one. Participants were asked to respond to the items on a seven-point Likert-type scale anchored by descriptors ranging from "Never" [0] to "Always" [6] indicating how often the respondent participated in various activities during the past three days/nights. Nineteen subscale scores were derived, which were further grouped into the following four major subscale groups:

- General Stress Subscale (General Stress, Emotional Stress, Social Stress, Conflicts/Pressure, Fatigue, Lack of Energy and Physical Complaints).

- General Recovery Activity Subscale (Success, Social Recovery, Physical Recovery, General Well-being and Sleep Quality). 
- $\quad$ Sport-specific Stress Subscale (Disturbed Breaks, Burnout/Emotional Exhaustion and Fitness/ Injury).

- $\quad$ Sport-specific Recovery Activity Subscale (Fitness/Being in Shape, Personal Accomplishments, Self-efficacy and Self-regulation).

In the RESTQ-52 Sport, two items respectively contribute to each of the General Stress and General Recovery Activity subscales, with four items contributing to each of the Sportspecific Stress and Sport-specific Recovery Activity subscales. Construct validity has been reported for this instrument (Kellmann \& Kallus, 2001). Due to the small sample size validity will not be determined. In the present survey, acceptable Cronbach alphas (ranging from 0.58 - 0.88) were calculated for 15 of the 19 subscales. Four of the subscales yielded poor reliability scores (Lack of Energy $=0.34 ;$ Physical Complaints $=-0.02$; Social Recovery $=$ 0.39 ; Physical Recovery $=0.42$ ). As a result, these four subscales were removed from the data set and substituted by the two items from which they were each derived. Thereafter, the four major subscale groups were found to be reliable (General Stress major subscale group $=$ 0.81; General Recovery Activity major subscale group $=0.68$; Sport-specific Stress major subscale group $=0.67 ;$ Sport-specific Recovery Activity major subscale group $=0.86$ ).

\section{The Athlete Burnout Questionnaire (ABQ)}

The 15-item ABQ was developed by Raedeke and Smith (2001) as a valid and reliable measure of the following three burnout subscales (with five items contributing to each):

- $\quad$ Reduced Sense of Accomplishment (e.g., "It seems no matter what I do, I don't perform as well as I should").

- $\quad$ Sport Devaluation (e.g., "I have negative feelings toward sport").

- Emotional/Physical Exhaustion (e.g., "I am exhausted by the mental and physical demands of my sport").

For this study, the $\mathrm{ABQ}$ was adapted to be specific for the rugby population through minor word substitution (i.e., changing the word "sports" to "rugby") as was done by Creswell and Eklund (2006a; 2006b) in their studies on New Zealand rugby players. Participants responded to individual items on a five-point Likert-type scale anchored by descriptors ranging from "Almost never" [1] to "Most of the time" [5]. The Total Burnout Score was derived by averaging the three subscale scores. Internal consistency estimates observed in the present investigation (Cronbach alphas between 0.73 to 0.81 for the three subscales and the Total Burnout Score) were largely consistent with previous reports.

\section{The Stellenbosch Mood Scale (STEMS)}

The STEMS (Terry et al., 2003) is a dual-language (English and Afrikaans) version of the Brunel Mood Scale (BRUMS) questionnaire of Terry et al. (1999) which is a derivative of the Profile of Mood States (POMS) questionnaire of McNair et al. (1971). The STEMS consists of 24 items and measures six subscales, i.e. Tension, Depression, Anger, Vigour, Fatigue and Confusion, with four items contributing to each subscale. A Total Mood Disturbance Score was derived by subtracting the negative mood state scores from the Vigour score. Participants were asked to rate "How are you feeling right now" in terms of 24 mood descriptors on a five-point Likert-type scale, anchored by descriptors ranging from "Not at 
all" [0] to "Extremely" [4]. Acceptable Cronbach alpha coefficients (ranging from 0.65 to 0.87 ) were found with this dataset.

\section{Descriptive variables}

The following descriptive variables were recorded throughout the study period.

- $\quad$ Playing position (Forward or backline player).

- Experience level: Players were grouped into the following three groups:

- Very experienced group, i.e. players representing the $1^{\text {st }}$ team for $\geq 3$ years.

- Less experienced group, i.e., players with one or two years experience at this level.

- Novice group, i.e., players in their first season at this level.

- Starting status (For inclusion within a specific group, a player had to be included in that group for at least four of the seven games). Based on data obtained during the roundrobin matches, players were grouped into the following two categories:

- Regular starters (Included in the starting line-up for at least four of the matches).

- Non-starters/ reserves (Included in the match 22 on at least four of the occasions).

\section{Procedures}

This study was approved by the Ethics Committee of the North-West University, Potchefstroom Campus (Reference number: NWU-0064-08-S1). The head coach of the NWU-PRI senior $1^{\text {st }}$ team was informed about the nature and purpose of the study and was asked for consent, cooperation and input, which was provided. Multiple testing dates were scheduled from the start of pre-season training $\left(31^{\text {st }}\right.$ October 2007) until the completion of the round-robin stage of the FNB Varsity Cup tournament (26 $6^{\text {th }}$ March 2008).

Where possible, testing was scheduled before the mid-week mental skills training and video analysis sessions. The participants were informed about the nature and purpose of the study and all of the participants completed informed (written) consent forms before their first completion of the research instruments. Confidentiality of results was guaranteed and participation at each test point was voluntary. Instructions to the subjects included a statement aimed at discouraging socially desirable answers.

Since this study did not aim to investigate changes in the various subscale scores over time, but rather to compare the scores of different sub-groups of players, the average scores obtained by each subject over the seven test points were calculated and used in the statistical analysis (for the comparison involving playing position and experience level). For the comparison between the regular starters and the reserve players, only the average scores of the data gathered during the competition period (Test 6 \& Test 7) were used, as the possible influence of selection/non-selection and the resulting game-time is believed to be particularly relevant during this period. Also, only those players $(n=23)$ who were in the starting line-up or match-22 of the NWU-PRI's first team for at least four of the seven round-robin matches during the Varsity Cup tournament were included in this analysis. 


\section{Statistical analysis}

The Statistical Data Processing package STATISTICA (Statsoft Inc, 2007) was used for the statistical analysis and the level of statistical significance was set at $\mathrm{p}<0.05$. For the comparisons involving the forwards and backline players, as well as between the regular starters and reserves (two groups respectively), independent $t$-tests were performed, whilst a One Way Analysis of Variance (ANOVA) were used to determine statistically significant differences between the three groups with varying experience levels. The ANOVA's were followed by Tukey's post Hoc tests for unequal sample sizes. In addition, because the subjects were not randomly selected, effect sizes (ES) were used to indicate practical significant differences for the subscales at the various time points, in which: $E S=\left(M_{1}-\right.$ $\left.M_{2}\right) / s_{(\max )}$. Here, $M_{1}=$ the mean value of the first group in the comparison, $M_{2}=$ the mean value of the second group in the comparison and $\mathrm{s}_{(\max )}=$ the largest standard deviation of the two groups in the comparison. The calculated ES are expressed as Cohen's $d$-value and can be interpreted as follows: $d \approx 0.20,0.50$ and 0.80 respectively indicate small, moderate and large practical significant differences (Steyn, 2009).

\section{RESULTS AND DISCUSSION}

Table 1 indicates the results of the comparison between the forwards and backline players for the various subscales. No significant age differences or numbers of years playing rugby were observed between players in the two positional groups. From these results it is evident that the forwards outperformed the backline players in all but one of the 39 variables in the analysis, whilst 21 of these variables were of moderate $(d \approx 0.5)$ practical significant magnitude. Although this comparison conclusively showed the forwards to have more favourable scores than the backline players, the results differ from Creswell and Eklund's (2006a) study on burnout among professional New Zealand rugby players. The forwards $(1.85 \pm 0.08)$ in their study were reported to have significantly $(\mathrm{p}=0.008)$ higher Sport Devaluation scores than the backline players $(1.58 \pm 0.09)$. Also, the forwards $(2.43 \pm 0.29)$ in the present study had significantly $(\mathrm{p}=0.062)$ higher Emotional/Physical Exhaustion scores than the backline players $(2.27 \pm 0.30)$, which can in part be attributed to the greater workloads performed by forwards during rugby matches (Deutsch et al., 1998). These conflicting results emphasise the need for further research in this regard, as this discrepancy either relates to the level of participation or other within-group influence(s) not accounted for in either/both of these studies. 


\section{TABLE 1. COMPARISON BETWEEN FORWARDS AND BACKLINE PLAYERS FOR THE RESTQ-52 SPORT, ABQ AND STEMS SUBSCALES}

\begin{tabular}{|c|c|c|c|c|}
\hline & $\begin{array}{l}\text { Forwards } \\
(\mathrm{n}=23)\end{array}$ & $\begin{array}{l}\text { Backline } \\
\text { players } \\
(\mathrm{n}=18)\end{array}$ & $\begin{array}{c}\text { Statistical } \\
\text { significance } \\
\text { (p value) }\end{array}$ & \begin{tabular}{|c|} 
Practical \\
significance \\
(Cohen's $d$ )
\end{tabular} \\
\hline Average age & $22.31 \pm 1.36$ & $22.18 \pm 1.47$ & 0.77 & 0.09 \\
\hline Average years playing rugby & $13.59 \pm 2.24$ & $14.00 \pm 2.61$ & 0.60 & 0.16 \\
\hline $\begin{array}{l}\text { TOTAL RECOVERY-STRESS (RESTQ- } \\
\text { SPORT) }\end{array}$ & $4.56 \pm 2.05$ & $3.35 \pm 1.80$ & $0.05^{\bullet}$ & $0.59^{\circ}$ \\
\hline 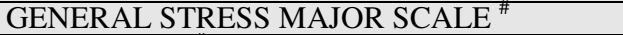 & $1.38 \pm 0.62$ & $1.57 \pm 0.68$ & 0.34 & 0.29 \\
\hline General Stress ${ }^{\#}$ & $1.05 \pm 0.69$ & $1.31 \pm 0.72$ & 0.24 & $0.37^{\circ}$ \\
\hline Emotional Stress \# & $1.26 \pm 0.68$ & $1.49 \pm 0.62$ & 0.26 & 0.34 \\
\hline Social Stress ${ }^{\#}$ & $1.30 \pm 0.81$ & $1.55 \pm 0.76$ & 0.33 & 0.30 \\
\hline Conflicts/Pressure \# & $2.00 \pm 0.97$ & $2.23 \pm 1.08$ & 0.48 & 0.21 \\
\hline Fatigue $\#^{\#}$ & $1.47 \pm 0.66$ & $1.48 \pm 0.80$ & 0.97 & 0.01 \\
\hline Item 6 - I had difficulties in concentrating \# & $1.54 \pm 0.60$ & $1.88 \pm 0.95$ & 0.17 & $0.36^{\circ}$ \\
\hline Item 23 - I put off making decisions $\#$ & $1.25 \pm 0.67$ & $1.60 \pm 0.87$ & 0.15 & $0.40^{\circ}$ \\
\hline Item 9 - I had a headache & $1.05 \pm 0.70$ & $0.97 \pm 0.89$ & 0.75 & 0.09 \\
\hline Item 12 - I felt uncomfortable ${ }^{\#}$ & $1.32 \pm 0.87$ & $1.46 \pm 0.85$ & 0.62 & 0.16 \\
\hline GENERAL RECOVERY MAJOR SCALE & $3.65 \pm 0.71$ & $3.31 \pm 0.53$ & 0.08 & $0.48^{\circ}$ \\
\hline Success & $3.28 \pm 0.89$ & $2.84 \pm 0.52$ & 0.07 & $0.50^{\circ}$ \\
\hline Item 2 - I laughed & $3.81 \pm 0.81$ & $3.80 \pm 0.67$ & 0.95 & 0.02 \\
\hline Item 8 - I had a good time with my friends & $3.80 \pm 1.13$ & $3.55 \pm 0.89$ & 0.45 & 0.22 \\
\hline Item 4 - I felt physically relaxed & $3.00 \pm 0.68$ & $2.75 \pm 0.79$ & 0.28 & 0.31 \\
\hline Item 21 - I felt as if I could get everything done & $3.29 \pm 0.94$ & $2.80 \pm 0.67$ & 0.07 & $0.51^{\circ}$ \\
\hline General Well-being & $3.83 \pm 0.82$ & $3.50 \pm 0.67$ & 0.13 & $0.39^{\circ}$ \\
\hline Sleep Quality & $4.21 \pm 0.96$ & $3.76 \pm 0.81$ & 0.12 & $0.47^{\circ}$ \\
\hline SPORT-SPECIFIC STRESS MAJOR SCALE ${ }^{\#}$ & $1.26 \pm 0.51$ & $1.67 \pm 0.73$ & $0.04 *$ & $0.56^{\circ}$ \\
\hline Disturbed Breaks & $1.01 \pm 0.59$ & $1.35 \pm 0.62$ & 0.08 & $0.55^{\circ}$ \\
\hline Burnout/Emotional Exhaustion ${ }^{\#}$ & $0.81 \pm 0.54$ & $1.08 \pm 0.75$ & 0.19 & $0.36^{\circ}$ \\
\hline Injury ${ }^{\#}$ & $1.96 \pm 0.68$ & $2.58 \pm 1.05$ & $0.03 *$ & $0.59^{\circ}$ \\
\hline SPORT-SPECIFIC RECOVERY MAJOR SCALE & $3.55 \pm 0.86$ & $3.29 \pm 0.55$ & 0.27 & 0.30 \\
\hline Being in shape & $3.58 \pm 0.84$ & $3.27 \pm 0.67$ & 0.22 & $0.36^{\circ}$ \\
\hline Personal accomplishment & $3.21 \pm 1.01$ & $2.89 \pm 0.65$ & 0.24 & 0.32 \\
\hline Self-efficacy & $3.73 \pm 0.94$ & $3.43 \pm 0.64$ & 0.25 & 0.32 \\
\hline Self-regulation & $3.68 \pm 1.00$ & $3.57 \pm 0.71$ & 0.70 & 0.11 \\
\hline TOTAL BURNOUT SCORE (ABQ) ${ }^{\#}$ & $1.71 \pm 0.39$ & $1.96 \pm 0.48$ & 0.07 & $0.53^{\circ}$ \\
\hline Reduced Sense of Accomplishment & $2.14 \pm 0.53$ & $2.38 \pm 0.52$ & 0.15 & $0.45^{\circ}$ \\
\hline Sport Devaluation ${ }^{\#}$ & $1.39 \pm 0.47$ & $1.58 \pm 0.54$ & 0.25 & 0.34 \\
\hline Emotional/Physical Exhaustion ${ }^{\#}$ & $1.61 \pm 0.38$ & $1.94 \pm 0.52$ & $0.02 *$ & $0.64^{\circ}$ \\
\hline TOTAL MOOD DISTURBANCE SCORE (STEMS) & $-1.23 \pm 8.06$ & $-5.66 \pm 12.0$ & 0.17 & $0.37^{\circ}$ \\
\hline Tension $^{\#}$ & $2.10 \pm 1.76$ & $3.36 \pm 3.39$ & 0.13 & $0.37^{\circ}$ \\
\hline Depressive mood $^{\#}$ & $1.41 \pm 1.78$ & $2.23 \pm 2.34$ & 0.21 & $0.35^{\circ}$ \\
\hline Anger ${ }^{\#}$ & $1.79 \pm 1.88$ & $2.13 \pm 1.90$ & 0.57 & 0.18 \\
\hline Vigour & $9.58 \pm 2.18$ & $8.98 \pm 2.13$ & 0.39 & 0.27 \\
\hline Fatigue ${ }^{\#}$ & $3.86 \pm 1.35$ & $4.19 \pm 1.92$ & 0.52 & 0.17 \\
\hline Confusion $^{\#}$ & $1.65 \pm 1.63$ & $2.74 \pm 2.93$ & 0.14 & $0.37^{\circ}$ \\
\hline
\end{tabular}

\# Lower values represent better results

Values in bold depict the group with the more favourable results for the particular subscale

* Statistically significant differences $(\mathrm{p}<0.05)$

- Borderline statistical significant difference $(\mathrm{p}=0.052)$

- Moderate practical significant differences $(d \approx 0.5)$ 


\section{TABLE 2. COMPARISON OF THE RESTQ-52 SPORT SUBSCALES BETWEEN THE GROUPS OF VERY EXPERIENCED, LESS EXPERIENCED AND NOVICE PLAYERS}

\begin{tabular}{|c|c|c|c|c|c|c|c|}
\hline & \multirow[b]{2}{*}{\begin{tabular}{|c|} 
Group 1 \\
Very \\
experienced \\
players \\
$(\geq 3$ years $)$ \\
$(\mathrm{n}=12)$ \\
\end{tabular}} & \multirow{2}{*}{$\begin{array}{c}\frac{\text { Group } 2}{\text { Less }} \\
\text { experienced } \\
\text { players } \\
\left(\begin{array}{c}1 \text { or } 2 \text { years }) \\
(\mathrm{n}=15)\end{array}\right. \\
\end{array}$} & \multirow{2}{*}{\begin{tabular}{|c|} 
Group 3 \\
Novice \\
players \\
$(0$ years at \\
this level $)$ \\
$(\mathrm{n}=14)$
\end{tabular}} & \multirow{2}{*}{$\begin{array}{c}\text { Analysis of } \\
\text { variance } \\
\text { (ANOVA) } \\
\text { Statistical } \\
\text { significance } \\
\text { (p value) }\end{array}$} & \multicolumn{3}{|c|}{ Effect size results (Cohen's $d$-value) } \\
\hline & & & & & \begin{tabular}{|c|} 
Practical \\
significance \\
between \\
Groups \\
$1 \& 2$ \\
\end{tabular} & $\begin{array}{c}\text { Practical } \\
\text { significance } \\
\text { between } \\
\text { Groups } \\
1 \& 3\end{array}$ & $\begin{array}{c}\text { Practical } \\
\text { significance } \\
\text { between } \\
\text { Groups } \\
2 \& 3\end{array}$ \\
\hline Average age & $23.15 \pm 0.99$ & $22.67 \pm 1.33$ & $21.05 \pm 0.85$ & $\leq 0.01^{*}$ & $0.36^{\circ}$ & $2.11^{\circ \circ}$ & $1.21^{\circ \circ}$ \\
\hline Years playing rugby & $15.25 \pm 1.66$ & $13.57 \pm 2.06$ & $12.71 \pm 2.70$ & $0.02 *$ & $0.81^{\circ 0}$ & $0.94^{\circ 0}$ & 0.32 \\
\hline $\begin{array}{l}\text { TOTAL RECOVERY- } \\
\text { STRESS (RESTQ-52) }\end{array}$ & $\underline{3.30 \pm 2.00}$ & $4.49 \pm 2.25$ & $4.17 \pm 1.70$ & 0.30 & $0.53^{\circ}$ & $0.44^{\circ}$ & 0.14 \\
\hline $\begin{array}{l}\text { GENERAL STRESS } \\
\text { MAJOR SCALE }^{\#}\end{array}$ & $\underline{1.77 \pm 0.66}$ & $1.11 \pm 0.48$ & $1.58 \pm 0.64$ & $0.02 *$ & $1.00^{\circ 0}$ & 0.30 & $0.72^{\circ \circ}$ \\
\hline General Stress Minor $^{\#}$ & $\underline{1.50 \pm 0.68}$ & $0.83 \pm 0.62$ & $1.23 \pm 0.70$ & $0.04 *$ & $0.98^{\circ \circ}$ & $0.37^{\circ}$ & $0.58^{\circ}$ \\
\hline Emotional Stress ${ }^{\#}$ & $\underline{1.75 \pm 0.68}$ & $1.08 \pm 0.46$ & $1.36 \pm 0.68$ & $0.02 *$ & $0.99^{\circ \circ}$ & $0.62^{\circ}$ & $0.37^{\circ}$ \\
\hline Social Stress $\#$ & $\underline{1.81 \pm 0.88}$ & $0.99 \pm 0.59$ & $1.51 \pm 0.72$ & $0.02 *$ & $0.93^{\circ \circ}$ & 0.34 & $0.73^{\circ \circ}$ \\
\hline Conflicts/Pressure ${ }^{\#}$ & $\underline{2.36 \pm 1.13}$ & $1.67 \pm 0.78$ & $2.35 \pm 1.04$ & 0.11 & $0.61^{\circ}$ & 0.01 & $0.65^{\circ}$ \\
\hline Fatigue $^{\#}$ & $1.72 \pm 0.76$ & $1.20 \pm 0.68$ & $1.56 \pm 0.66$ & 0.15 & $0.68^{\circ \circ}$ & 0.21 & $0.52^{\circ}$ \\
\hline $\begin{array}{l}\text { Item } 6 \text { - I had difficul- } \\
\text { ties in concentrating }\end{array}$ & $1.82 \pm 0.55$ & $1.38 \pm 0.82$ & $\underline{1.92 \pm 0.86}$ & 0.15 & $0.54^{\circ}$ & 0.11 & $0.62^{\circ}$ \\
\hline $\begin{array}{l}\text { Item } 23 \text { - I put off } \\
\text { making decisions }\end{array}$ & $\underline{1.70 \pm 1.00}$ & $1.12 \pm 0.67$ & $1.45 \pm 0.59$ & 0.15 & $0.58^{\circ}$ & 0.25 & $0.49^{\circ}$ \\
\hline $\begin{array}{l}\text { Item 9- I had a } \\
\text { headache }\end{array}$ & $1.06 \pm 0.64$ & $0.61 \pm 0.56$ & $\underline{1.39 \pm 0.93}$ & $0.02 *$ & $0.70^{\circ \circ}$ & $0.35^{\circ}$ & $0.84^{\circ \circ}$ \\
\hline $\begin{array}{l}\text { Item } 12 \text { - I felt } \\
\text { uncomfortable }\end{array}$ & $\underline{1.96 \pm 0.74}$ & $0.93 \pm 0.65$ & $1.36 \pm 0.87$ & $\leq 0.01 *$ & $1.39^{\circ \circ}$ & $0.69^{\circ 0}$ & $0.50^{\circ}$ \\
\hline $\begin{array}{l}\text { GENERAL RECOVE- } \\
\text { RY MAJOR SCALE }\end{array}$ & $\underline{3.37 \pm 0.62}$ & $3.41 \pm 0.82$ & $3.72 \pm 0.44$ & 0.25 & 0.05 & $0.56^{\circ}$ & $0.38^{\circ}$ \\
\hline Success & $\underline{2.88 \pm 0.75}$ & $3.01 \pm 0.89$ & $3.35 \pm 0.63$ & 0.27 & 0.15 & $0.63^{\circ}$ & $0.39^{\circ}$ \\
\hline Item 2 - I laughed & $3.86 \pm 0.79$ & $\underline{3.66 \pm 0.93}$ & $3.92 \pm 0.45$ & 0.65 & 0.21 & 0.07 & 0.27 \\
\hline $\begin{array}{l}\text { Item } 8 \text { - I had a good } \\
\text { time with my friends }\end{array}$ & $3.73 \pm 1.16$ & $\underline{3.21 \pm 1.02}$ & $4.17 \pm 0.71$ & $0.04 *$ & $0.45^{\circ}$ & $0.38^{\circ}$ & $0.94^{\circ \circ}$ \\
\hline $\begin{array}{l}\text { Item } 4 \text { - I felt physically } \\
\text { relaxed }\end{array}$ & $2.67 \pm 0.51$ & $3.07 \pm 1.01$ & $2.90 \pm 0.49$ & 0.36 & $0.40^{\circ}$ & $0.46^{\circ}$ & 0.17 \\
\hline $\begin{array}{l}\text { Item } 21 \text { - I felt as if I } \\
\text { could get everything } \\
\text { done }\end{array}$ & $\underline{2.77 \pm 0.58}$ & $3.17 \pm 0.98$ & $3.23 \pm 0.90$ & 0.34 & $0.41^{\circ}$ & $0.52^{\circ}$ & 0.06 \\
\hline General Well-being & $\underline{3.61 \pm 0.74}$ & $3.68 \pm 0.94$ & $3.76 \pm 0.61$ & 0.57 & 0.07 & 0.21 & 0.09 \\
\hline Sleep Quality & $3.85 \pm 0.85$ & $\underline{3.79 \pm 0.95}$ & $4.38 \pm 0.87$ & 0.17 & 0.07 & $0.60^{\circ}$ & $0.62^{\circ}$ \\
\hline
\end{tabular}




\begin{tabular}{|c|c|c|c|c|c|c|c|}
\hline & \multirow[b]{2}{*}{$\begin{array}{c}\frac{\text { Group } 1}{\text { Very }} \\
\text { experienced } \\
\text { players } \\
(\geq 3 \text { years }) \\
(\mathrm{n}=12)\end{array}$} & \multirow[b]{2}{*}{\begin{tabular}{|c|} 
Group 2 \\
Less \\
experienced \\
players \\
$(1$ or 2 years $)$ \\
$(\mathrm{n}=15)$ \\
\end{tabular}} & \multirow[b]{2}{*}{\begin{tabular}{|l|} 
Group 3 \\
Novice \\
players \\
$(0$ years at \\
this level) \\
$(\mathrm{n}=14)$
\end{tabular}} & \multirow[b]{2}{*}{$\begin{array}{c}\text { Analysis of } \\
\text { variance } \\
\text { (ANOVA) } \\
\text { Statistical } \\
\text { significance } \\
\text { (p value) }\end{array}$} & \multicolumn{3}{|c|}{ Effect size results (Cohen's $d$-value) } \\
\hline & & & & & $\begin{array}{l}\text { Practical } \\
\text { significance } \\
\text { between } \\
\text { Groups } \\
1 \& 2 \\
\end{array}$ & \begin{tabular}{|c|} 
Practical \\
significance \\
between \\
Groups \\
$1 \& 3$ \\
\end{tabular} & \begin{tabular}{|c|} 
Practical \\
significance \\
between \\
Groups \\
$2 \& 3$ \\
\end{tabular} \\
\hline $\begin{array}{l}\text { SPORT-SPECIFIC } \\
\text { STRESS MAJOR } \\
\text { SCALE }^{\#}\end{array}$ & $1.66 \pm 0.69$ & $1.18 \pm 0.51$ & $1.53 \pm 0.68$ & 0.13 & $0.70^{\circ \circ}$ & 0.20 & $0.51^{\circ}$ \\
\hline Disturbed Breaks \# & $\underline{1.38 \pm 0.52}$ & $0.85 \pm 0.59$ & $1.31 \pm 0.64$ & $0.05^{*}$ & $0.90^{\circ \circ}$ & 0.11 & $0.70^{\circ \circ}$ \\
\hline $\begin{array}{l}\text { Burnout/ Emotional } \\
\text { Exhaustion }{ }^{\#}\end{array}$ & $\underline{1.07 \pm 0.77}$ & $0.73 \pm 0.52$ & $1.03 \pm 0.65$ & 0.31 & $0.44^{\circ}$ & 0.04 & $0.47^{\circ}$ \\
\hline Injury $^{\#}$ & $\underline{2.55 \pm 1.00}$ & $1.97 \pm 0.71$ & $2.25 \pm 0.98$ & 0.26 & $0.58^{\circ}$ & 0.30 & 0.28 \\
\hline $\begin{array}{l}\text { SPORT-SPECIFIC } \\
\text { RECOVERY MAJOR } \\
\text { SCALE }\end{array}$ & $\underline{3.36 \pm 0.78}$ & $3.38 \pm 0.86$ & $3.56 \pm 0.59$ & 0.75 & 0.02 & 0.25 & 0.21 \\
\hline Being in shape & $\underline{3.26 \pm 0.71}$ & $3.45 \pm 1.00$ & $3.59 \pm 0.55$ & 0.56 & 0.20 & $0.47^{\circ}$ & 0.14 \\
\hline $\begin{array}{l}\text { Personal } \\
\text { accomplishment }\end{array}$ & $3.21 \pm 0.88$ & $\underline{2.90 \pm 0.92}$ & $3.13 \pm 0.84$ & 0.63 & 0.34 & 0.08 & 0.26 \\
\hline Self-efficacy & $\underline{3.49 \pm 0.77}$ & $3.49 \pm 0.99$ & $3.80 \pm 0.69$ & 0.53 & 0.00 & $0.41^{\circ}$ & 0.31 \\
\hline Self-regulation & $\underline{3.49 \pm 1.03}$ & $3.69 \pm 0.86$ & $3.70 \pm 0.81$ & 0.82 & 0.17 & 0.20 & 0.04 \\
\hline
\end{tabular}

\# Lower values represent better results

Values in bold depict the group with the best results for the particular subscale, whilst underlined values represent the group with the least favourable results

* Statistically significant differences $(\mathrm{p}<0.05)$

- Moderate practical significant differences $(d \approx 0.5)$

${ }^{\circ}$ Large practical significant differences $(d \approx 0.8)$

Table 2 shows that the level of experience is age dependent, as the group of very experienced rugby players at this particular level of participation ( $23.15 \pm 0.99$ years) was significantly older than the novice players $(21.05 \pm 0.85$ years). Similarly, the group of very experienced players $(15.25 \pm 1.66$ years) had been participating in rugby for significantly longer than their less experienced $(13.57 \pm 2.06$ years) and novice $(12.71 \pm 2.70$ years $)$ counterparts respectively. The less experienced group reported the lowest scores of the three groups for the Total Recovery-Stress Score and all of the General and Sport-Specific Stress Major Scales and Subscales. The novice players had the highest General and Sport-Specific Recovery Scores of the three groups, except for the Physical Relaxation item and the Personal Accomplishment subscale. To the best of our knowledge, no studies have been published in which the REST-Q scores of athletes with different experience levels have been compared, thereby limiting the extent to which the current results can be discussed.

From Table 3 it is evident that moderate practical significant $(d \approx 0.5)$ differences exist for Sport Devaluation between the very experienced players (who had the highest values) and the novice players. Furthermore, the very experienced group had higher Total Burnout, Reduced Sense of Accomplishment and Emotional/Physical Exhaustion scores than the other groups, 
albeit insignificantly so. In this regard Creswell and Eklund (2006a), revealed that professional New Zealand rugby players with greater national level experience reported significantly $(\mathrm{p}<0.05)$ higher Sport Devaluation and Emotional/Physical Exhaustion scores than those players without such experience. Prolonged representation at a particular level, therefore, seems to increase a player's chances of burning out.

\section{TABLE 3. COMPARISON OF THE ABQ AND STEMS SUBSCALES BETWEEN THE GROUPS OF VERY EXPERIENCED, LESS EXPERIENCED AND NOVICE PLAYERS}

\begin{tabular}{|c|c|c|c|c|c|c|c|}
\hline & \multirow[b]{2}{*}{$\begin{array}{l}\text { Group } 1 \\
\text { Very ex- } \\
\text { perienced } \\
\text { players } \\
(\geq 3 \text { years }) \\
(\mathrm{n}=12)\end{array}$} & \multirow[b]{2}{*}{\begin{tabular}{|c|} 
Group 2 \\
Less \\
experienced \\
players $(1$ or \\
2 years $)$ \\
$(\mathrm{n}=15)$
\end{tabular}} & \multirow[b]{2}{*}{$\begin{array}{l}\text { Group } 3 \\
\text { Novice } \\
\text { players } \\
(0 \text { years at } \\
\text { this level) } \\
(\mathrm{n}=14)\end{array}$} & \multirow[b]{2}{*}{$\begin{array}{c}\text { Analysis of } \\
\text { variance } \\
\text { (ANOVA) } \\
\text { Statistical } \\
\text { significance } \\
\text { (p-value) }\end{array}$} & \multicolumn{3}{|c|}{$\begin{array}{c}\text { Effect size results (Cohen's } d \\
\text { value) }\end{array}$} \\
\hline & & & & & \begin{tabular}{|c|} 
Practical \\
signifi- \\
cance \\
between \\
Groups \\
$1 \& 2$ \\
\end{tabular} & $\begin{array}{c}\text { Practical } \\
\text { signifi- } \\
\text { cance } \\
\text { between } \\
\text { Groups } \\
1 \& 3 \\
\end{array}$ & $\begin{array}{c}\text { Practica } \\
\text { signifi- } \\
\text { cance } \\
\text { between } \\
\text { Groups } \\
2 \& 3 \\
\end{array}$ \\
\hline $\begin{array}{l}\text { TOTAL BURNOUT } \\
\text { SCORE (ABQ) }{ }^{\#}\end{array}$ & $1.93 \pm 0.65$ & $1.77 \pm 0.33$ & $1.79 \pm 0.33$ & 0.63 & 0.24 & 0.22 & 0.04 \\
\hline $\begin{array}{l}\text { Reduced Sense of } \\
\text { Accomplishment }{ }^{\#}\end{array}$ & $\underline{2.30 \pm 0.76}$ & $2.18 \pm 0.41$ & $2.26 \pm 0.43$ & 0.86 & 0.15 & 0.04 & 0.18 \\
\hline Sport Devaluation ${ }^{\#}$ & $1.63 \pm 0.67$ & $1.44 \pm 0.45$ & $1.38 \pm 0.37$ & 0.42 & 0.29 & $0.38^{\circ}$ & 0.15 \\
\hline $\begin{array}{l}\text { Emotional/Physical } \\
\text { Exhaustion\# }\end{array}$ & $1.85 \pm 0.64$ & $1.70 \pm 0.42$ & $1.72 \pm 0.37$ & 0.68 & 0.25 & 0.20 & 0.06 \\
\hline $\begin{array}{l}\text { TOTAL MOOD } \\
\text { DISTURBANCE } \\
\text { SCORE (STEMS) } \\
\end{array}$ & $-6.69 \pm 11.66$ & $-0.11 \pm 8.03$ & $-3.45 \pm 10.37$ & 0.25 & $0.56^{\circ}$ & 0.28 & 0.32 \\
\hline Tension $^{\#}$ & $3.38 \pm 3.07$ & $1.77 \pm 1.66$ & $2.97 \pm 3.01$ & 0.25 & $0.52^{\circ}$ & 0.13 & $0.40^{\circ}$ \\
\hline Depression $^{\#}$ & $2.61 \pm 2.65$ & $1.11 \pm 1.33$ & $1.77 \pm 2.00$ & 0.17 & $0.56^{\circ}$ & 0.32 & 0.32 \\
\hline Anger ${ }^{\#}$ & $2.76 \pm 2.21$ & $1.34 \pm 1.35$ & $1.88 \pm 1.91$ & 0.14 & $0.64^{\circ}$ & $0.40^{\circ}$ & 0.29 \\
\hline Vigour & $9.38 \pm 2.21$ & $9.00 \pm 2.69$ & $9.61 \pm 1.47$ & 0.75 & 0.14 & 0.10 & 0.23 \\
\hline Fatigue $^{\#}$ & $4.57 \pm 1.63$ & $3.62 \pm 1.83$ & $3.93 \pm 1.29$ & 0.32 & $0.52^{\circ}$ & $0.39^{\circ}$ & 0.17 \\
\hline Confusion ${ }^{\#}$ & $2.76 \pm 2.23$ & $1.27 \pm 1.16$ & $2.52 \pm 3.10$ & 0.19 & $0.67^{\circ}$ & 0.08 & $0.40^{\circ}$ \\
\hline
\end{tabular}

\# Lower values represent better results

Values in bold depict the group with the best results for the particular subscale, whilst underlined values represent the group with the least favourable results

- Moderate practical significant differences $(d \approx 0.5)$

The very experienced group consistently showed significantly greater $(d \approx 0.5)$ Total Mood Disturbance Score and negative mood state scores (i.e., Tension, Depression, Anger, Fatigue and Confusion) than the less experienced group. Insignificant differences were also observed for the Vigour subscale, with the novice group showing the highest scores.

Previous research has shed light on the impact of players' experience levels on their burnout scores. Burnett (2003) noted that by becoming an established member of a team, a player's personal involvement deepens, resulting in stronger commitments and greater responsibility. According to Creswell and Eklund (2005), such additional responsibilities within the team include leadership roles and tactical decision making duties, which may contribute to an 
imbalance between the perceived demands on the player and the capacity of the player to handle such responsibilities, thereby increasing the risk for burning out.

For the comparison involving starting status, only 23 players were included in the analysis (see the subsection on the subjects for inclusion criteria). Table 4 reveals that the regular starters were significantly older and had been playing rugby for longer than the reserves. The reserve players showed significantly better Total Recovery-Stress $(d=0.46)$, General Recovery $(d=0.46)$, Sport-specific Recovery $(d=0.46)$ and Total Mood Disturbance Scores $(d=0.73)$ scores than those in the starting line-up. In fact, the reserves had significantly better scores for all six Mood State subscales than those in the starting line-up.

The regular starters, however, had less Sport-specific Stress and lower Sport Devaluation and Emotional/Physical Exhaustion values than the reserves, albeit insignificantly so. Creswell and Eklund (2006a) previously found that players not in the starting line-up $(2.35 \pm 0.22)$ had significantly $(\mathrm{p}=0.025)$ higher Reduced Sense of Accomplishment levels than those in the starting line-up $(2.18 \pm 0.21)$, but the current findings failed to substantiate these results.

\section{TABLE 4. COMPARISON BETWEEN REGULAR FIRST TEAM STARTERS AND NON-STARTERS (RESERVES) FOR THE RESTQ-52 SPORT, ABQ AND STEMS SUBSCALES}

\begin{tabular}{|c|c|c|c|c|}
\hline & 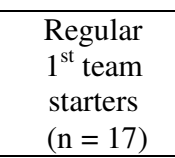 & $\begin{array}{c}\text { Regular non- } \\
\text { starters/ } \\
\text { reserves } \\
(\mathrm{n}=6)\end{array}$ & \begin{tabular}{|c|}
$T$-test results \\
Statistical \\
significance \\
(p-value) \\
\end{tabular} & $\begin{array}{l}\text { Effect sizes } \\
\text { Practical } \\
\text { significance } \\
(\text { Cohen's } d) \\
\end{array}$ \\
\hline Average age & $22.92 \pm 1.23$ & $21.71 \pm 1.98$ & 0.09 & $0.61^{\circ}$ \\
\hline Average years playing rugby & $14.53 \pm 2.03$ & $11.50 \pm 3.94$ & $0.02 *$ & $0.77^{\circ \circ}$ \\
\hline $\begin{array}{l}\text { TOTAL RECOVERY-STRESS (RESTQ- } \\
\text { SPORT) }\end{array}$ & $3.56 \pm 2.21$ & $4.58 \pm 2.24$ & 0.34 & $0.46^{\circ}$ \\
\hline GENERAL STRESS MAJOR SCALE $^{\#}$ & $1.48 \pm 0.82$ & $1.26 \pm 0.56$ & 0.56 & 0.26 \\
\hline General Stress Minor ${ }^{\#}$ & $1.29 \pm 0.89$ & $1.04 \pm 0.77$ & 0.55 & 0.28 \\
\hline Emotional Stress ${ }^{\#}$ & $1.51 \pm 1.10$ & $1.21 \pm 0.53$ & 0.52 & 0.28 \\
\hline Social Stress $\#$ & $1.51 \pm 0.92$ & $1.29 \pm 0.66$ & 0.59 & 0.24 \\
\hline Conflicts/Pressure $^{\#}$ & $2.09 \pm 1.27$ & $1.92 \pm 0.80$ & 0.76 & 0.14 \\
\hline Fatigue $^{\#}$ & $1.41 \pm 1.00$ & $1.33 \pm 0.97$ & 0.87 & 0.08 \\
\hline Item 6 - I had difficulties in concentrating ${ }^{\#}$ & $1.56 \pm 0.95$ & $1.25 \pm 0.76$ & 0.48 & 0.33 \\
\hline Item 23 - I put off making decisions ${ }^{\#}$ & $1.44 \pm 1.12$ & $0.83 \pm 0.82$ & 0.24 & $0.54^{\circ}$ \\
\hline Item 9 - I had a headache ${ }^{\#}$ & $0.62 \pm 0.74$ & $0.75 \pm 0.76$ & 0.71 & 0.17 \\
\hline Item 12 - I felt uncomfortable ${ }^{\#}$ & $1.41 \pm 1.03$ & $1.25 \pm 1.08$ & 0.75 & 0.15 \\
\hline GENERAL RECOVERY MAJOR SCALE & $3.20 \pm 0.75$ & $3.63 \pm 0.92$ & 0.28 & $0.46^{\circ}$ \\
\hline Success & $2.91 \pm 0.80$ & $3.04 \pm 1.02$ & 0.75 & 0.13 \\
\hline Item 2 - I laughed & $3.35 \pm 1.04$ & $3.92 \pm 1.20$ & 0.29 & $0.47^{\circ}$ \\
\hline Item 8 - I had a good time with my friends & $3.24 \pm 1.40$ & $3.75 \pm 1.44$ & 0.45 & $0.36^{\circ}$ \\
\hline Item 4 - I felt physically relaxed & $2.59 \pm 0.87$ & $3.25 \pm 0.61$ & 0.10 & $0.76^{\circ \circ}$ \\
\hline $\begin{array}{l}\text { Item } 21 \text { - I felt as if I could get everything } \\
\text { done }\end{array}$ & $2.91 \pm 0.83$ & $3.17 \pm 1.47$ & 0.61 & 0.17 \\
\hline General Well-being & $3.26 \pm 0.92$ & $3.79 \pm 1.12$ & 0.27 & $0.47^{\circ}$ \\
\hline Sleep Quality & $3.79 \pm 0.96$ & $4.25 \pm 1.01$ & 0.34 & $0.45^{\circ}$ \\
\hline
\end{tabular}




\begin{tabular}{|c|c|c|c|c|}
\hline & $\begin{array}{l}\text { Regular } \\
1^{\text {st }} \text { team } \\
\text { starters } \\
(\mathrm{n}=17) \\
\end{array}$ & $\begin{array}{c}\text { Regular non- } \\
\text { starters/ } \\
\text { reserves } \\
(\mathrm{n}=6)\end{array}$ & \begin{tabular}{|c|}
$T$-test results \\
Statistical \\
significance \\
(p-value) \\
\end{tabular} & $\begin{array}{l}\text { Effect sizes } \\
\text { Practical } \\
\text { significance } \\
(\text { Cohen's } d \text { ) } \\
\end{array}$ \\
\hline $\begin{array}{l}\text { SPORT-SPECIFIC STRESS MAJOR } \\
\text { SCALE }^{\#}\end{array}$ & $1.28 \pm 0.78$ & $1.35 \pm 0.58$ & 0.85 & 0.08 \\
\hline Disturbed Breaks ${ }^{\#}$ & $0.92 \pm 0.81$ & $1.13 \pm 0.63$ & 0.58 & $0.25^{\circ}$ \\
\hline Burnout/ Emotional Exhaustion $^{\#}$ & $0.93 \pm 0.77$ & $0.98 \pm 0.61$ & 0.90 & 0.06 \\
\hline Injury $^{\#}$ & $1.99 \pm 1.12$ & $1.94 \pm 0.74$ & 0.91 & 0.05 \\
\hline $\begin{array}{l}\text { SPORT-SPECIFIC RECOVERY MAJOR } \\
\text { SCALE }\end{array}$ & $3.11 \pm 0.82$ & $3.56 \pm 0.97$ & 0.28 & $0.46^{\circ}$ \\
\hline Being in shape & $3.11 \pm 0.85$ & $3.67 \pm 0.97$ & 0.20 & $0.58^{\circ}$ \\
\hline Personal accomplishment & $2.80 \pm 0.86$ & $3.29 \pm 1.19$ & 0.29 & $0.41^{\circ}$ \\
\hline Self-efficacy & $3.23 \pm 1.09$ & $3.63 \pm 1.03$ & 0.45 & $0.36^{\circ}$ \\
\hline Self-regulation & $3.31 \pm 0.92$ & $3.67 \pm 0.91$ & 0.42 & $0.39^{\circ}$ \\
\hline TOTAL BURNOUT SCORE (ABQ) ${ }^{\#}$ & $1.81 \pm 0.64$ & $1.81 \pm 0.35$ & 0.99 & 0.00 \\
\hline Reduced Sense of Accomplishment ${ }^{\#}$ & $2.31 \pm 0.67$ & $2.18 \pm 0.43$ & 0.67 & 0.19 \\
\hline Sport Devaluation $^{\#}$ & $1.49 \pm 0.71$ & $1.58 \pm 0.47$ & 0.77 & 0.13 \\
\hline Emotional/Physical Exhaustion ${ }^{\#}$ & $1.62 \pm 0.69$ & $1.65 \pm 0.41$ & 0.93 & 0.04 \\
\hline $\begin{array}{l}\text { TOTAL MOOD DISTURBANCE SCORE } \\
\text { (STEMS) }\end{array}$ & $-1.00 \pm 11.25$ & $7.25 \pm 3.17$ & 0.10 & $0.73^{\circ \circ}$ \\
\hline Tension $^{\#}$ & $2.15 \pm 2.97$ & $0.92 \pm 0.74$ & 0.33 & $0.41^{\circ}$ \\
\hline Depression $^{\#}$ & $1.35 \pm 2.00$ & $0.25 \pm 0.42$ & 0.20 & $0.55^{\circ}$ \\
\hline Anger ${ }^{\#}$ & $1.35 \pm 1.97$ & $0.50 \pm 0.84$ & 0.32 & $0.43^{\circ}$ \\
\hline Vigour & $8.24 \pm 3.10$ & $10.25 \pm 1.70$ & 0.15 & $0.65^{\circ \circ}$ \\
\hline Fatigue $^{\#}$ & $2.50 \pm 2.08$ & $1.00 \pm 1.58$ & 0.12 & $0.72^{\circ \circ}$ \\
\hline Confusion $^{\#}$ & $1.88 \pm 2.79$ & $0.33 \pm 0.52$ & 0.20 & $0.56^{\circ}$ \\
\hline
\end{tabular}

\# Lower values represent better results

Values in bold depicts the group with the best results for the particular subscale

* Statistically significant differences $(\mathrm{p}<0.05)$

- Moderate practical significant differences $(d \approx 0.5)$

$\circ$ Large practical significant differences $(d \approx 0.8)$

Collectively, the results from Table 4 suggest that the players in the starting line-up were subject to greater stress levels, had poorer recovery strategies and generally experienced greater negative mood state scores than the reserve players, whereas the reserves experienced greater stress of a sport-specific nature.

\section{CONCLUSIONS}

The results from this study show that playing position, experience level and starting status are related to the key characteristics of burnout, the recovery-stress balance and mood states, as significant differences in these scores were frequently observed between the various subgroups. Importantly, these differences do not imply prediction or causation.

In particular, it was observed that the forwards in the current investigation had more favourable REST-Q, ABQ and STEMS subscale scores than the backline players. The very experienced players (senior squad members) at this particular participation level showed the 
least favourable REST-Q, ABQ and STEMS subscale scores throughout. Players with limited experience at this level (one or two years) had the most favourable Total Recovery-Stress, General Recovery, Sport-specific Recovery, Burnout and Mood State scores of the three groups in the comparison, whilst the novice players (first season at this level) showed the most favourable General Recovery and Sport-specific Recovery scores. Starting status were also shown to significantly affect the Total Recovery-Stress, General Recovery Major Scale, Sport-specific Recovery Major Scale and the Total Mood Disturbance scores with the reserves showing more favourable results than the regular starters.

\section{RECOMMENDATIONS}

From these findings it is recommended that different player management strategies should be developed and implemented for more experienced team members and regular starters. Playing position should also be considered when monitoring and managing rugby players regarding the possible onset and development of the overtraining and burnout syndromes.

This study used an availability sample consisting of 41 male student rugby players. The small number of participants potentially limits the ability to generalize these results to other populations, especially as this group was further divided into subgroups for the various comparisons. It is subsequently recommended that future studies include larger sample sizes comprising of players from different teams. The inclusion of players from different teams would enable comparisons between successful and less successful teams, thereby contributing to the existing knowledge of factors leading to the development of overtraining and burnout. Furthermore, it is suggested that this study is extended to professional rugby players competing at the provincial and/or international level, as these players are particularly prone to experience these syndromes due to year-round competitive seasons with short breaks in between.

\section{ACKNOWLEDGEMENT}

The research team is sincerely grateful to the NWU-PRI senior training squad members and management staff, especially to head coach Matthew Proudfoot, for continued cooperation and input throughout the study period.

\section{REFERENCES}

BURNETT, C. (2003). The multi-faceted development of the athlete-student in the South African context. African Journal for Physical, Health Education, Recreation and Dance, 9(1): 1-19.

CRESWELL, S.L. \& EKLUND, R.C. (2003). The athlete burnout syndrome: A practitioner's guide. New Zealand Journal of Sports Medicine, 31(1): 4-9.

CRESWELL, S.L. \& EKLUND, R.C. (2005). Changes in athlete burnout and motivation over a 12 week league tournament. Medicine and Science in Sports and Exercise, 37(11): 1957-1966.

CRESWELL, S.L. \& EKLUND, R.C. (2006a). Changes in athlete burnout over a thirty-week "rugby year". Journal of Science and Medicine in Sport, 9(1-2): 125-134.

CRESWELL, S.L. \& EKLUND, R.C. (2006b). The convergent and discriminant validity of burnout measures in sport: A multi-trait/multi-method analysis. Journal of Sports Sciences, 24(2): 209220. 
CRESWELL, S.L. \& EKLUND, R.C. (2006c). The nature of player burnout in rugby: Key characteristics and attributions. Journal of Applied Sport Psychology, 18(3): 219.

DEUTSCH, M.U.; MAW, G.J.; JENKINS, D. \& REABURN, P. (1998). Heart rate, blood lactate and kinematic data of elite colts (under-19) rugby union players during competition. Journal of Sports Sciences, 16(6): 561-570.

GOULD, D. \& DIEFFENBACH, K. (2002). Overtraining, under-recovery, and burnout in sport. In M. Kellmann (Ed.), Enhancing recovery: Preventing underperformance in athletes (25-35). Champaign, IL: Human Kinetics.

GROBBELAAR, H.W.; MALAN, D.D.J.; STEYN, B.J.M. \& ELLIS, S.M. (2010). Monitoring the burnout levels and recovery-stress balance of elite student rugby players over time. Journal of Sports Sciences [submitted for publication].

KELLMANN, M. \& KALLUS, K.W. (2001). Recovery-stress questionnaire for athletes: user manual. Champaign, IL: Human Kinetics.

KENTTÄ, G. \& HASSMÉN, P. (1998). Overtraining and recovery. A conceptual model. International Journal of Sports Medicine, 26(1): 1-16.

KENTTÄ, G.; HASSMÉN, P. \& RAGLIN, J.S. (2001). Training practices and overtraining syndrome in Swedish age-group athletes. International Journal of Sports Medicine, 22(6): 460-465.

MARSHALL, J. (2005). How youth coaches are using a psychological questionnaire to deal with 'underperformance syndrome'. In S. Bordiss (Ed.), Training for rugby (83-93). London: Peak Performance Publishing.

MASHIKO, T.; UMEDA, T.; NAKAJI, S. \& SUGUWARA, K. (2004). Position related analysis of the appearance of and relationship between post-match physical and mental fatigue in university rugby football players. British Journal of Sports Medicine, 38: 617-621.

McNAIR, D.M.; LORR, M. \& DROPPLEMAN, L.F. (1971). Manual for the profile of mood states. San Diego, CA: Educational and industrial testing services.

RAEDEKE, T.D. \& SMITH, A.L. (2001). Development and preliminary validation of an athlete burnout measure. Journal of Sport and Exercise Psychology, 23(4): 281-306.

RAEDEKE, T.D.; LUNNEY, K. \& VENABLES, K. (2002). Understanding athlete burnout: Coach perspectives. Journal of Sport Behavior, 25(2): 181-201.

RAGLIN, J.S. \& WILSON, G.S. (2000). Overtraining in athletes. In Y.L. Hanin (Ed.), Emotions in sport (191-207). Champaign, IL: Human Kinetics.

STATSOFT (2007). Statistica for Windows: General conventions and statistics. Tilsa, OK: StatSoft.

STEYN, H.S. (2009). "Manual for the determination of effect size indices and practical significance." Hyperlink [http://www.puk.ac.za/opencms/export/PUK/html/fakulteite/natuur/skd/ handleiding_e.html]. Retrieved 1 July 2009.

TERRY, P.C.; LANE, A.M.; LANE, H.J. \& KEOHANE, L. (1999). Development and validation of a mood measure for adolescents. Journal of Sports Sciences, 17(11): 861-872.

TERRY, P.C.; POTGIETER, J.R. \& FOGARTY, G.J. (2003). The Stellenbosch mood scale: A duallanguage measure of mood. International Journal of Sport and Exercise Psychology, 1(3): 231245.

THELWELL, R.C.; WESTON, N.J.V.; LANE, A.M. \& GREENLEES, I.A. (2006). Relation of game location and experience on mood states. Perceptual and Motor Skills, 102(1): 157-162.

Dr. Heinrich Grobbelaar: Department of Sport Science, Stellenbosch University, Private bag X1, Matieland 7602, Republic of South Africa. Tel.: +27 (0)21 8084771 (w), Fax.: +27 (0)21 808 4817, Email: hgrobbelaar@sun.ac.za

(Subject editor: Prof. J.R. Potgieter) 